\title{
The Analysis of Metaphorical Perceptions of Teachers Related to Teachers in terms of Teaching Approaches They Adopt
}

\author{
Burcu Akkaya ${ }^{1}$ \\ ${ }^{1}$ Ministry of National Education, Turkish Language and Literature Teacher, Eskisehir, Turkey \\ Correspondence: Burcu Akkaya, Ministry of National Education, Turkish Language and Literature Teacher, \\ Eskisehir, Turkey. E-mail: akkaya.eyt@gmail.com. ORCID: 0000-0002-4571-9065
}

Received: June 28, 2021

Accepted: August 7, $2021 \quad$ Online Published: August 30, 2021

doi:10.5539/jel.v10n5p109

URL: https://doi.org/10.5539/jel.v10n5p109

\begin{abstract}
This research aimed to determine the metaphorical perceptions of class teachers and reveal whether these perceptions are affected by the teaching approaches they adopt. Because teachers' opinions were collected in written form, this study is a descriptive survey model study. The participants of the study consisted of 64 class teachers chosen through the maximum variety sampling method. A data collection tool consisting of two open-ended questions was developed to determine the metaphors and educational approaches teachers adopt. According to research results, teacher metaphors are highlighted in two categories as "metaphors giving active roles to the teacher" and "metaphors giving passive roles to the teacher". Generally, teachers adopted one of the behaviouristic, cognitive, and constructivist approaches. This study revealed that participants who adopted behavioural and cognitive educational approaches produced metaphors giving active roles to the teacher. Participants who adopted the constructivist educational approach produced metaphors giving passive roles to the teacher. It was determined that there is a strong significant relationship between the metaphors that teachers produce and the educational approach they adopt.
\end{abstract}

Keywords: class teachers, metaphor, metaphors about teachers, teaching approaches

\section{Introduction}

Education is a process to guide learning to explore knowledge and skills that individuals will need throughout their lives and consider that each individual is unique. Undoubtedly, an important part of this guiding process is experienced at schools through teachers' hands in a planned and programmed fashion. Thus, in a changing and developing world, the teacher factor is considered to realise, evaluate, and reach the aims. Studies are held concerning the teacher and teaching profession, teacher development programs are developed, and roles and competencies concerning teachers are defined.

Teacher and teaching are multidimensional terms consisting of a variety of invisible factors. Metaphors are used to (i) make the invisible visible, (ii) define the dimensions and (iii) examine them in detail to study these concepts. This is because metaphors are figurative uses of language that can realise the activities in the three items mentioned above and make the meaning out of the topic.

Teacher related metaphors were the research subject of this study. Moreover, the metaphors produced by the teachers were also investigated in terms of their preferred educational approach. Firstly, the views of behaviourist, cognitive, and constructivist approaches related to the teacher were presented. Then, metaphors and teacher metaphors were examined, and the research report was presented.

\subsection{Teacher Concept in Educational Approaches}

Schools are educational institutions where educational services are provided and have shareholders like students, teachers, principals, auxiliary services, and support personnel, parents, and visitors. By coordinating these shareholders, schools help reach the ultimate aims. Basaran (2008) pinpoints that the teacher concept appeared because of instructor search of families who were insufficient against increased knowledge and skills; schools appeared because of the improving relationship between instructing and instructed. According to the researcher, everybody in teaching, from kindergarten to university, are classified as teachers no matter what title they hold. Similarly, according to Marshall (2014), the teacher realises the teaching process in a school/institution. Definitions related to teacher concepts vary according to the educational approach adopted. In other words, each 
approach, namely behaviourist, cognitive, and constructivist, defined education and concepts related to education differently and organised teaching-learning processes following the items and values emphasised in these definitions. Thus, to present the sources of differences in these definitions, first, education, learning-teaching, student concepts were cleared, and then the teacher concept was presented.

\subsubsection{Education}

Since the 1900s, three basic approaches, behaviourist, cognitive, and constructivist, have been adopted and utilised in education. The behaviourist approach spread to many countries and became significantly effective in the 1950s. It then left its place to the cognitive approach in the 1960s. With the increase in studies on the learning process and brain structure in 1980, the constructivist approach became the main topic of interest. In Turkey, traditional teaching approaches were abandoned in 2004. A variety of approaches and models (multiple intelligences, brain-based learning, skills approach, etc.) were utilised in the constructivist approach (Gunes, 2010). The definitions of education made by these three approaches differ from each other greatly. First of all, in the behaviourist approach, education is defined as making intended and terminal behaviours in an individual through their experiences (Erturk, 1975), equipping an individual with terminal behaviours (Sonmez, 2001) or behaviour change processes (Demirel, Seferoglu \& Yagci, 2003; Sonmez, 2000). On the other hand, the cognitivist approach defined education as making meaning by processing the data reaching the human mind (Bower \& Hilgard, 1981) or processes of receiving, processing, and forming new concepts of the outside stimulants (Gunes, 2010). Finally, the constructivist approach defined education as processes where individuals recreate the reality they choose from their environment freely (Biggs, 1996) or recreate subjective meanings formed in individual cognition through interactions with other individuals in a sociocultural context (Yurdakul, 2007).

It is obvious in all three approaches that the definitions related to education are consistent that "education is a process". Moreover, to be able to talk about education, a change has to happen. However, it is also safe to say that the differences in all three approaches exceed the similarities. For example, the individual is considered passive in the behaviourist approach, and educational processes are only interested in input and output without changing the mind. Yet, in the cognitive approach, it could be mentioned that education is interested in activities like thinking, comprehension, judging, questioning, and memorising. On the other hand, in the constructivist approach, the individual is active, and knowledge and education activities are organised in terms of interest, skills, desires, and needs of an individual. Regarding these explanations, education could be defined as "the process of guiding the learning of an individual keeping in mind that every individual is unique, and they have to explore knowledge and skill they would need throughout their lives".

\subsubsection{Teaching-Learning}

Behaviourist, cognitivist, and constructivist approaches also defined teaching-learning concepts differently. For example, learning in the behaviourist approach is defined as transferring the reality in the outside world to an individual (Biggs, 1996), equipping the individual with terminal behaviours (Sonmez, 2001), and the change which happens by bonding various behaviours and stimulants (repetition activities, punishment, and reward applications, etc.) used to figure out behaviours and reaction (Gunes, 2007). Learning in the cognitive approach, on the other hand, is an active and complex change happening in an individual's mind (Resnick, 1989). It is a neurophysiological process where mind exercises, behaviour changes, and motivation happens (Alkan, 1992) or meaning-making process of an individual using their conscious to help gain knowledge, make plans and find solutions to problems (Selcuk, 1997). In the constructivist approach, as emphasised by Piaget, learning is defined as change, which assimilation (understanding new information through existing knowledge) and compliance (changing existing knowledge to be able to react to new information) (Piaget, 1928), processing, interpreting and constructing knowledge in the mind (Gunes, 2007).

Similarly, definitions concerning teaching concepts also differ. The principles and methods of the behaviourist approach were acquired through animal experiments held by the researchers like Pavlov, Thorndike, and Skinner. The principles attained from these experiments were transferred to human education. According to the behaviourist approach, intended behaviours could be taught permanently to the individual by giving stimulus, forming a response and repetition. In this approach, teaching is shortly changing behaviours. In the cognitive approach, teaching is defined as providing instinctive processes like memory, remembering, and creativity to be reflected. In the constructivist approach, teaching is being a source, guide, and helper to an individual to combine their existing partial knowledge in the face of new events and thus construct what they know against stimulants (Alkan, 1992; Gunes, 2010; Piaget, 1928; Selcuk, 1997; Yurdakul, 2007). 


\subsubsection{Teacher-Learner}

Teacher-learner concepts which are shortly defined as teaching-learning individuals in educational institutions were defined differently in different educational approaches as in education and teaching-learning concepts. In the behaviouristic approach, students are empty buckets to fill who makes predicted reactions and get all the knowledge from the teacher. On the other hand, teachers fill knowledge to these buckets, intending to bring in intended behaviours (Gunes, 2010). In the cognitive approach, while students were defined as individuals who gain knowledge, make plans, and solve problems, teachers were defined as people who give necessary stimulants to help students gain the outcomes and organise education settings consistent with this aim. In the constructivist approach, students are defined as active, questioning, researching knowledge instead of getting it prepared, knowing how to use it, being aware of their learning style, and creating new knowledge. On the other hand, teachers stimulate students' background knowledge, know and consider their interests, demands, and needs, get between students and thoughts via various questions, direct them to question, and guide learning (Gunes, 2010; Yurdakul, 2007).

As seen above, education and many education-related concepts were defined in various ways in behaviourist, cognitive, and constructivist approaches. Among the many concepts whose definition differs in the approaches is the teacher. In the behaviourist approach, the teacher is defined as the person who fulfils teaching/transferring knowledge and plays an active role in the education process. In contrast, in the cognitive approach, it is defined as the person who organises the educational environment and gives necessary stimulants for students to gain planned aims and behaviours determined beforehand. Finally, in the constructivist approach, the teacher is the more passive person than the two other approaches, who guides students to reach information, use it, and produce new information. In this research, since learners are considered passive, the "traditional education approach" term was used instead of behaviouristic and cognitive education approaches. Furthermore, the "contemporary education approach" term was used instead of the constructivist approach seeing the learner as active.

\subsection{Metaphor}

The term metaphor is based on the ancient Greek term metaphérō, which means transform, alteration, and carry. Later, the term was transferred to French and English and gained new meanings as "transfer, alteration, and using a word out of its natural meaning". According to the Turkish Language Society (2020), one word can have multiple meanings or figures of speech used in a meaning other than its real meaning because of an interest or assimilation.

Metaphors, which help define the unknown through the known in a language, have gained interest and been the subject of various studies. Therefore, it is possible to find various definitions of metaphor. For instance, Cerit (2008) defined metaphors as tools that people use to explain events and subjects through different assimilations. A metaphor is a basic mechanism of the mind helping to understand one thing via another (Lakoff \& Johnson, 2015). Similarly, Arnett (1999) associated metaphors with mental processes and defined them as an auxiliary tool to help understand what's happening in the outside world. Metaphors that could shortly be defined as a figure of speech suggest new ways to examine events while interpreting unknown social reality through the known ones with the help of assimilations (Balci, 2010) and analyse complex concepts and phenomena (Midgley \& Trimmer, 2013).

Additionally, metaphors have natural and strong abilities to realise the emotional, sensory, and complex dimensions of phenomena (Black, 2013). When an object of experience is used by using another object of experience, metaphors are used; thus, it is claimed that object A is Object B or similar to it (Morgan, 1998). In other words, metaphors are used to understand something by looking at it from a different perspective (Creed, 2013).

Metaphors are important language characteristics that predict different words, allow for creativity, and shape our perceptions and understandings related to social circumstances (Palmquist, 2001). Many people perceive these characteristics as a subject related to words, not thoughts and movements. However, Lakoff and Johnson (2015) claim that metaphors are used excessively in daily life and have important effects not only in language but also in thoughts and movement. According to them, our natural conceptual system, which designates our thoughts and movements, is essentially metaphoric. According to Strensky (1989), metaphors reflect our thoughts, shape them and, as a result, determine behaviours (Cited in. Arslan \& Bayrakci, 2006). Similarly, Morgan (1998) pinpointed that metaphors have deeper meanings than the art of uttering flourished words. In general, metaphors are a way of thinking about how we perceive and see the world. Many studies in various fields revealed that metaphors profoundly impact thinking, language, science, and individual expressions. 
Metaphors are used with a variety of aims in education. To illustrate, in structuring and modelling supervision theories, psychophysical skills education, program development and planning processes, stimulating learning and developing creativity metaphors are used. Moreover, metaphors are also used in teacher education, notably in teaching applications and defining teacher roles following the skills and abilities needed in the era (Parmar et al., 2016; Vadeboncoeur \& Torres, 2003).

It is not always possible to define an object, concept or phenomenon using the available words in a language. Furthermore, humans flourish the expression and harmonise the literary work they create using emotions, thoughts, and dreams by adding aesthetic values to utter fancy words. It is also possible to come across efforts to be more comprehensible in daily language, use more concrete expressions, and explain the unknown. One of the most common methods to fulfil these goals is to draw an analogy/transfer. These expressions help us describe a phenomenon or an object using known words, thus, make them concrete, visible, and understandable.

The metaphors based on the reasons mentioned above are used in various fields from management to medicine, engineering, education, etc. Trying to describe an organisation using the machine metaphor and developing a management model according to that metaphor is used in the management field. The bone between the breast bones and shoulders is called the collarbone (Latin clavicula "little key") because it rotates along its axis like a key when the shoulder is abducted; this is an example of a metaphor in medicine. Metaphors are commonly encountered in the education field. Especially in today's world where the constructivist approach is forefronted, the first tools to fulfil learning from abstract to concrete and from known to unknown are metaphors. Metaphors are commonly used with concepts related to physics, chemistry, and biology to make them clear. Moreover, it is also safe to say that metaphors are highly used in pre-service and in-service education of teachers, equipping them with professional competencies, determining occupational perceptions and helping them be aware of their perceptions. The focus of this study was to determine the perceptions of teachers in in-service training related to teachers through metaphors and to investigate whether there is a relationship between their adopted educational approach and the metaphors they use.

\subsection{Teacher Metaphors}

Teachers constitute one of the most important aspects of the education process and have various responsibilities. Organising teaching-learning processes and the choice of educational methods and strategies are among these responsibilities. Teachers who fulfil these functions make important changes in the academic success and personal behaviours of the students. Determining how teachers, who shape the behaviours of individuals, are perceived by students, teachers, and other shareholders is relatively important (Cerit, 2008). Many studies may be encountered in the literature (Aydin \& Pehlivan, 2010; Ben-Peretz, Mendelson, \& Kron, 2003; Biggs, 1996; Cerit, 2008; Celikten, 2006; Oguz, 2009; Parmar et al., 2016; Ward, 2013) on how teachers are perceived by educational shareholders like themselves, students, and school administrators.

Oxford et al. (1998) classified metaphors used in the education field in their studies. Researchers put metaphors they gathered through a variety of written and oral data from teachers and students into four main categories by relating them to the functions of education as (i) providing social order, (ii) culture transfer, (iii) being student-centred, and (iv) social reform. According to this, education has a duty of providing social order. In this respect, teachers are defined through metaphors such as "social engineer", "producer", doctor", and "corrective of mind and behaviour". Among the many duties of education is providing cultural transfer. In the scope of this study, a teacher is defined through the "controller" metaphor. On the other hand, being student-centred consists of activities to be held to reveal the students' full potential by improving their skills. Teachers are best defined as "the creator of the most suitable atmosphere to the mind". Finally, in the social reform category, organising education following social needs and improving it in the best way possible are mentioned. In this process, the teacher is defined through the "learning partner" metaphor.

In a study conducted by Cakmak (2021), it was determined that teacher candidates explained the teaching profession with 108 different metaphors and teachers explained the teaching profession with 52 different metaphors. Teacher candidates and teachers used 21 common metaphors when describing the teaching profession. These metaphors; tree, family, mother, gardener, flower, growing flowers, farmer, sun, rainbow, life, light, pen, pole star, candle, muralist, navigation, orchestra conductor, compass, artist, water, and soil. As a result, it has been revealed that both teacher candidates and teachers have common perceptions about the teaching profession.

Another study on metaphors was conducted by Ucar and Parlak-Rakap (2021). In the research conducted with the participation of 259 pre-service teachers, 232 metaphors for the teacher were obtained. Pre-service teachers mostly compared the teacher to parents, guides, and gardeners. The metaphors developed for the teacher in the 
classroom were combined in the categories of teacher as a family member, shaping teacher, pioneer teacher and producing teacher.

In their research, Sokmen, Kilic, and Yildirim (2020) aimed to reveal the metaphors of primary school teacher candidates and primary school teachers regarding the concept of teacher. In the research, 104 metaphors were obtained. These metaphors were gathered in six categories as (i) information source (ii) productive and formative (iii) remedial and restorative (iv) guiding and directing (v) exemplary and (vi) reassuring. Among these categories, it was observed that the primary school teacher candidates mostly used the metaphor of parents and candles $(\mathrm{n}=18)$, and the classroom teachers mostly used the sun metaphor $(\mathrm{n}=10)$. As a result, it was determined that the metaphors produced by all participants were generally positive.

In their study, De Guerro \& Vilamil (2001) determined 28 teacher metaphors according to the opinions of 112 participants. These metaphors are put in nine general categories. Researchers stated that participants used the "leader", "trainer", "maestro", "sun", and "gardener" metaphors the most.

In their study, Vadebonceur \& Torres (2003) pinpointed that metaphors are used in teaching applications and redefining teacher roles following the era's needs. Moreover, researchers stated that teacher candidates used six metaphors related to teacher concepts: gardener, knowledge provider, change agent, intermediary, architect, and researcher.

Saban (2004) aimed to determine teachers' metaphors related to their perception of the teacher concept; most participants defined teachers with their traditional roles (providing knowledge, shaping, rehabilitating). A small number of participants supported the opinions that teachers should entertain while teaching to support students' improvement and guidance.

In their study, Celikten (2006) suggested that the thoughts and applications of teachers could be improved through metaphors. According to the researcher, metaphors are the tools that help teachers understand and digest their roles and responsibilities. Teachers' beliefs related to education affect their behaviours during the education process and even their commitment to the profession's ethical principles.

Cerit (2008) determined the perceptions of students, teachers, and principals on the concept of teacher, revealed that participants mostly used positive metaphors. Moreover, most participants agreed that teachers are the source of knowledge, producer and distributor, illuminate the environment and guides. On the other hand, most participants did not agree that teachers are bossy, an element of oppression and guardian.

Oguz (2009) held a study to reveal teacher candidates' perceptions of who would work in secondary education institutions on secondary school teachers through metaphors. In the study, teacher candidates, who were enrolled in secondary education field teaching programs, stated the first five metaphors representing teachers in their field were football coach, compass, researcher, guide, and leader.

Teacher metaphors are used to reveal the roles of teachers, their beliefs and assumptions about education, and determine the factors lying beneath (Ben-Peretz, Mendelson, \& Kron, 2003). Moreover, it could also be claimed that through teacher metaphors, teachers' perceptions related to their profession could be determined, and they are given the opportunity to realise their perceptions.

This study aimed to reveal the metaphorical perceptions of class teachers working in state primary schools in Nigde Province on teacher concepts and whether these perceptions are affected by their adopted educational approach. Through the general aim of the study, answers for the following questions were sought:

1) What are the metaphors related to teachers used by teachers whose service period is between 1-15 years?

2) What are the metaphors used by teachers related to teachers whose service period is 16 years or more?

3) What educational approach did teachers whose service period is between 1-15 years adopt?

4) What educational approach did teachers whose service period is 16 years or more adopt?

\section{Methodology}

This study aimed to investigate teachers' metaphorical perceptions of teachers and whether these perceptions are affected by the education approach they adopted as a descriptive study in the survey model. Since teachers' opinions were collected in written form, the qualitative research method was applied to analyse the data. Qualitative research is flexible, and this flexibility is applicable for all the steps of the research process, including sampling (Yildirim \& Simsek, 2000)

\subsection{Study Group/Participants}

The study participants consisted of class teachers working at some state primary schools in Niğde Province in 
2020. During the selection of the teachers, "maximum variety" sampling of purposeful sampling methods was used. Purposeful sampling is to pick cases with knowledge-rich content to go deeper in the research (Patton, 2002). The researcher decided to use purposeful sampling because the researcher knows the area well and can choose participants with rich information concerning the study's aims. Participants of the study were 64 class teachers. The distribution of participants related to their gender, age, service period variables is presented in Table 1 below.

Table 1. The distribution of participants related to different variables

\begin{tabular}{llll}
\hline & & f & $\mathbf{\%}$ \\
\hline Gender & Female & 33 & 51.56 \\
Age & Male & 31 & 48.44 \\
& $21-28$ & 10 & 15.62 \\
& $29-36$ & 11 & 17.19 \\
& $37-44$ & 9 & 14.06 \\
Period of Service & $45-52$ & 15 & 23.44 \\
& 53 and over & 19 & 29.69 \\
& $1-5$ & 10 & 15.62 \\
& $6-10$ & 12 & 18.76 \\
& $11-15$ & 10 & 15.62 \\
& $16-20$ & 14 & 21.88 \\
& 21 and over & 18 & 28.12 \\
\hline
\end{tabular}

According to Table 1, the participants consisted of 33 females (51.56\%) and 31 males (48.44). The participants were mostly within the 45-52 and 53+ age groups. The number of participants at the 21-28, 29-36, and 37-44 age groups was similar. Half of the participants had been teaching for 15 years, and the other half for 16 years or more.

\subsection{Collection of Data}

A one-question open-ended data collection tool was developed inspired by forms used by Culha-Ozbas (2012), Soysal and Afacan (2012) in the literature to determine the metaphors used by participating teachers related to teacher concept. Moreover, to determine the relationship between the teachers' metaphors and the education approach they adopted, a second open-ended question was added to the questionnaire. The form consists of two parts. The first part of the form had personal information (gender, age, service period), and the second part consisted of open-ended questions. Participants were asked to complete the "A teacher is like ......... Because ......." sentence for the first question. The second question aimed to determine the teachers preferred/adopted education approach.

\subsection{Data Analysis}

The content analysis method was used in the analysis of the collected data. Content analysis aims to decipher the truth hidden in the data (Corbin \& Strauss, 1990). Categories/themes are determined with this aim, and then the data are coded in these categories/themes and findings are interpreted (Creswell, 2012). Categories (themes) were formed at the beginning of the study using the deductive method. Accordingly, four categories were determined as (i) metaphors giving teachers active roles, (ii) metaphors giving teachers passive roles, (iii) traditional, and (iv) contemporary. Teachers' opinions related to teacher metaphors were re-coded by an expert other than the researcher, and the reliability of the study was calculated using the reliability formula provided by Miles \&Huberman (2015). For coding to be reliable, at least a 70\% agreement is necessary (Houten \& Hall, 1983 cited in Taskin, 2014). The reliability coefficient was calculated as $82 \%$; thus, the study was considered reliable.

\section{Findings}

Under this heading, results and interpretations are presented.

\subsection{The Opinions of Participants Related to Teacher Metaphor}

Participants" answers to the question "Teacher is like........ because........" were evaluated in two categories as metaphors giving teachers active roles and metaphors giving teachers passive roles. According to this, metaphors produced by participants as "source of knowledge, knowledge transfer, shaper, harvester, sculptor, farmer, machine, engine, maestro, director, boss, carpenter, gardener, captain, construction foreman, mother and father" were grouped under the "metaphors giving teacher an active role" category, and metaphors such as 
"guide, pathfinder, candle, light, sun, compass, traffic signs, mirror, sky and ocean" were put in the "metaphors giving teachers a passive role" category. 64 (33 females and 31 males) people participated in the study. Because each participant expressed an opinion, the number of opinions show the number of participants at the same time. Since traditional education approaches were abandoned in Turkey starting from 2004, it was thought that contemporary education approaches had been adopted, and teacher candidates have been raised accordingly in education faculties. Thus, it was determined that teachers who graduated after this date and started working would be appropriate to be evaluated together and be meaningful and explanatory the teachers' opinions with 1-5 years, 6-10 years, and 11-15 years of service period were evaluated together. Therefore, teachers having 16-20 years and 21 and more years of service period were considered out of this span, assuming they were educated in a more traditional approach. These two groups were evaluated together. In the following paragraphs, first, the findings and the interpretations of these findings of the first group who were educated with contemporary education approaches, then the second group who were educated in traditional education approaches were presented.

\subsubsection{The Opinions of Participants with a Service Period Less than 15 Years Related to Teacher Metaphor}

A total of 8 participants, 4 with 1-5 years of service period and 4 with $6-10$ years of service period, expressed opinions on the "metaphors giving teachers an active role" category. Participants with 11-15 years of service period did not make any comments on this category. As for the "metaphors giving teachers passive roles" category, 6 teachers with 1-5 years of service period, 8 teachers with 6-10 years of service period, and ten teachers with 11-15 years of service period (24 in total) expressed opinions (see Table 2 below). According to Table 2, it is seen that all the participants expressed opinions (24) on the "metaphors giving passive role" category. Eight of these opinions belonged to female participants, while 16 belonged to males. The most common three opinions were "sun", "candle", and "guide" metaphors in this category. On the other hand, in the "metaphors giving active roles" category, eight opinions were expressed. Three of these opinions belonged to female teachers, while five of them belonged to male teachers. The most common opinion in this category was the "sculptor" metaphor.

Table 2. The distribution of participant opinions on teacher metaphors

\begin{tabular}{|c|c|c|c|c|c|c|c|c|}
\hline & \multirow[t]{2}{*}{ Metaphor } & \multicolumn{2}{|c|}{$1-5$ years } & \multicolumn{2}{|c|}{$6-10$ years } & \multicolumn{2}{|c|}{ 11-15 years } & \multirow[t]{2}{*}{ Total } \\
\hline & & $\mathbf{F}$ & $\mathbf{M}$ & $\mathbf{F}$ & $\mathbf{M}$ & $\mathbf{F}$ & $\mathbf{M}$ & \\
\hline Metaphors giving active & knowledge transmitter & 1 & & & & & & 1 \\
\hline \multirow[t]{6}{*}{ roles } & sculptor & & 1 & & 2 & & & 3 \\
\hline & shepherd & & & & 1 & & & 1 \\
\hline & maestro & & & 1 & & & & 1 \\
\hline & director & 1 & & & & & & 1 \\
\hline & carpenter & & 1 & & & & & 1 \\
\hline & Total & 2 & 2 & 1 & 3 & - & - & 8 \\
\hline Metaphors giving & guide & & 2 & 2 & & & & 4 \\
\hline \multirow[t]{10}{*}{ passive roles } & pathfinder & & 1 & & & & 1 & 2 \\
\hline & candle & 1 & 1 & & 1 & & 1 & 4 \\
\hline & lamp & & & 1 & 1 & & & 2 \\
\hline & light & & & & & 1 & 1 & 2 \\
\hline & sun & & 1 & 2 & & 1 & 1 & 5 \\
\hline & compass & & & & 1 & & & 1 \\
\hline & traffic signs & & & & & & 1 & 1 \\
\hline & mirror & & & & & & 1 & 1 \\
\hline & sky & & & & & & 1 & 1 \\
\hline & ocean & & & & & & 1 & 1 \\
\hline Total & & 1 & 5 & 5 & 3 & 2 & 8 & 24 \\
\hline Grand Total & & 3 & 7 & 6 & 6 & 2 & 8 & 32 \\
\hline
\end{tabular}

When teachers' opinions with 15 years and less service periods on teacher metaphors are evaluated together, it is possible to say that these teachers consider teachers passive, guiding students in teaching-learning processes and help students learn. These findings contradict Saban's (2004) study but support Koc's (2014) study results. Saban (2004), in their study, determined that most of the teacher candidates (64\%) perceive the teacher as the source and transmitter of knowledge, shaper/moulder, and healer. Koc (2014), on the other hand, in their study held at Kastamonu University Faculty of Education, revealed that 168 teacher candidates produced 53 metaphors 
related to the teacher concept; these metaphors had positive connotations and resembled teachers to non-living things. They stated that the participants' first five metaphors were sun, light, candle, parent, and tree. The teacher candidates drew the analogy depending on the presenting knowledge, directing and providing improvement features of the teacher.

\subsubsection{The Opinions of Participants with a Service Period for 16 Years and Above Related to Teacher Metaphor}

Twelve participants with a service period of 16-20 years and 15 participants with 21 years and above (27 in total) presented opinions on the "metaphors giving active roles" category. As for the "metaphors giving passive roles" category, 2 of the teachers with 16-20 years of service period and 3 of the teachers with 21 years and above (5 in total) expressed their opinions (Table 3). According to Table 3, all the participants expressed their opinions (27) for the "metaphors giving active roles" category the most. Twenty of these opinions belonged to female teachers, while 7 of them belonged to males. The most common first two metaphors in this category were the "source of knowledge" and "shepherd" metaphors. As for the "metaphors giving passive roles" category, five opinions were expressed. Two of these opinions belonged to female teachers and three of them to male teachers. The most common opinion in this category was the "sun" metaphor.

When the opinions of teachers with 16 years and above service period related to teacher metaphors were evaluated together, it is possible to say that these teachers consider teachers more active in teaching-learning processes, offer knowledge pre-cooked for the students, keep the educational activities under control, and makes students passive as much as possible. Similarly, Chen (2003) claimed that teachers who are committed to traditional teaching methods keep the "strength" and "control" elements in the fore, behave in a way not to lose these elements, and tend to use metaphors following this axis. The results of this study are also similar to Nikitina and Furuoka's (2008) research results. The mentioned researchers determined that 98 participants produced 25 different metaphors, and these metaphors differed according to the participants' ages. According to the study results, participants used the furniture manufacturer, judge, boss, police, and gardener metaphors the most.

Table 3. Distribution of the opinions of participants related to teacher metaphors

\begin{tabular}{|c|c|c|c|c|c|c|}
\hline & \multirow[t]{2}{*}{ Metaphor } & \multicolumn{2}{|c|}{ 16-20 years } & \multicolumn{2}{|c|}{$21+$ years } & \multirow[t]{2}{*}{ Total } \\
\hline & & $\mathbf{F}$ & $\mathbf{M}$ & $\mathbf{F}$ & $\mathbf{M}$ & \\
\hline \multirow{19}{*}{$\begin{array}{l}\text { Metaphors giving active } \\
\text { roles }\end{array}$} & source of knowledge & 2 & & 1 & 1 & 4 \\
\hline & knowledge transmitter & 1 & & & & 1 \\
\hline & shaper & 1 & & & & 1 \\
\hline & harvester & & & & 1 & 1 \\
\hline & sculptor & & & & 2 & 2 \\
\hline & farmer & & & & 1 & 1 \\
\hline & shepherd & 1 & & 1 & 1 & 3 \\
\hline & machine & 1 & & & & 1 \\
\hline & engine & 1 & & & & 1 \\
\hline & maestro & 1 & & & & 1 \\
\hline & director & 1 & & & & 1 \\
\hline & boss & 1 & & & & 1 \\
\hline & carpenter & 1 & 1 & & & 2 \\
\hline & gardener & & & 1 & & 1 \\
\hline & captain & & & 1 & & 1 \\
\hline & construction foreman & & & 1 & & 1 \\
\hline & mother & & & 2 & & 2 \\
\hline & father & & & 2 & & 2 \\
\hline & Total & 11 & 1 & 9 & 6 & 27 \\
\hline \multirow{4}{*}{$\begin{array}{l}\text { Metaphors giving passive } \\
\text { roles }\end{array}$} & candle & & & & 1 & 1 \\
\hline & lamp & 1 & & & & 1 \\
\hline & sun & & 1 & & 1 & 2 \\
\hline & compass & & & 1 & & 1 \\
\hline Total & & 1 & 1 & 1 & 2 & 5 \\
\hline Grand Total & & 12 & 2 & 10 & 8 & 32 \\
\hline
\end{tabular}

\subsection{The Opinions of the Participants Related to the Educational Approach They Adopted}

The answers of the participants to the question "which education approach (behaviourist, cognitive, 
constructivist) do you prefer to organise your teaching-learning processes? Please, explain the activities you apply in your classroom with examples" were evaluated under two categories; "traditional" and "contemporary". The opinions of teachers who adopted behaviourist and cognitive approaches were coded in the "traditional" category, and the ones adopting the constructivist approach were coded in the "contemporary" category. Sixty-four teachers ( 33 females and 31 males) participated in the study. Because each participant expressed an opinion, the number of opinions, at the same time, presents the number of participants. In the coding of teachers' opinions related to teacher metaphors, in the coding of educational approach, two categories were formed as teachers with 15 years and less service period and teachers with 16 years and above. The findings and interpretations related to these groups are presented below.

3.2.1 The Opinions of Participants with a Service Period of 15 Years and Below Related to Educational Approach

A total of six participants, two with 1-5 years of service period, two with 6-10 years, and two with 11-15 years, expressed their opinions related to the "traditional" category. As for the "contemporary" category, eight teachers with 1-5 years of service period, ten of 6-10 years, and eight of 11-15 years (26 in total) expressed opinions. According to Table 4 below, it was seen that the participants expressed opinions to the "contemporary" category the most (26) related to the educational approach they adopted.

Table 4. The distribution of participant opinions related to the educational approach they adopted

\begin{tabular}{lllll}
\hline Educational Approach & $\mathbf{1 - 5}$ years & $\mathbf{6}-\mathbf{1 0}$ years & $\mathbf{1 1 - 1 5}$ years & Total \\
\hline Traditional & 2 & 2 & 2 & 6 \\
Contemporary & 8 & 10 & 8 & 26 \\
Total & 10 & 12 & 10 & 32 \\
\hline
\end{tabular}

3.2.2 The Opinions of Participants with a Service Period of 16 Years and Above Related to Educational Approach

Twelve participants with 16-20 years of service period, seventeen participants with 21 and above years (29 in total) expressed opinions related to the "traditional" category. As for the "contemporary" category, two participants with 16-20 years of service period and one of the participants with 21 and above years ( 3 in total) expressed opinions. According to Table 5 below, it was seen that the participants expressed opinions related to the "traditional" category (29) the most.

Table 5. The distribution of participant opinions related to the educational approach they adopted

\begin{tabular}{llll}
\hline Educational Approach & $\mathbf{1 6 - 2 0}$ years & $\mathbf{2 1 +}$ years & Total \\
\hline Traditional & 12 & 17 & 29 \\
Contemporary & 2 & 1 & 3 \\
Total & 14 & 18 & 32 \\
\hline
\end{tabular}

As seen above, all participants in both groups (15 years and less and 16 years and more) produced metaphors related to the teacher concept. In general, the number of metaphors "giving active roles" and the ones "giving passive roles" are equal. However, while 24 of 32 teachers with a service period of $1-15$ years produced metaphors giving passive roles, 8 produced metaphors giving active roles; 27 of 32 teachers with 16 years and more service period produced metaphors giving teachers active roles, and five produced metaphors giving teaches passive roles. In other words, the first group produced metaphors giving passive roles and the second group produced metaphors giving active roles to the teacher. As mentioned before, this difference is thought to occur due to adopting a constructivist approach after 2004 in Turkey because teachers in the first group were educated in education faculties arranged for this new educational approach. When teachers' opinions related to the educational approach they adopted were examined, similar results were acquired. In general, while 26 of 32 teachers with 1-15 years of service period preferred contemporary, six preferred the traditional education approach; 29 of 32 teachers with 15 years and more service period preferred traditional, three preferred contemporary approaches. These results suggest that the teacher metaphors differ according to service periods, hence their university education and their experiences there about the educational approach. Sachs (1999) claims that previous learning experiences have a strong impact on shaping identity. As claimed in many studies in the literature (Cusi \& Malara, 2016; Lipka \& Brinthaupt, 1999; Sachs, 1999; Szukala, 2011), many factors may 
affect the adopted education approach. For example, perceptions of the teaching profession might differ during the years to pass in the profession. Sociocultural aspects of society might change, and individual life circumstances might also differ.

\section{Discussion and Conclusion}

One of the methods to explain the unknown using the known terms in a language is to use assimilation/figurative speech. It is possible to encounter these expressions, also known as metaphors, in many science fields or disciplines such as medicine, physics, chemistry, and daily spoken languages. Similarly, in education, metaphors are used to create learning from known to unknown principles, in teacher education or in determining teacher candidates' perceptions related to the profession, and to help them realise these perceptions.

This research was created to determine teacher metaphors and matured with the researcher's curiosity about the reasons lying beneath the differences in metaphorical perceptions. In the literature review, it was seen that there are many studies aiming to reveal the metaphorical perceptions of teachers towards the teacher, but studies on how these perceptions differ are insufficient. No research has been found on whether teachers' metaphorical perceptions of teachers are affected by the educational approaches they adopt. Therefore, it is hoped that this study will fill this gap in the literature.

The aim of this research is to reveal whether teachers' metaphorical perceptions are affected by the educational approaches they adopt. This main purpose was studied through two sub-objectives: (i) teachers' metaphorical perceptions of teachers and (ii) teachers' teaching approaches. A data collection tool consisting of two open-ended questions was developed to determine the metaphors teachers use and the educational approaches they adopt.

According to the results of the research, it was determined that teachers were an "information source, information transmitter, shaper, combine harvester, sculptor, farmer, shepherd, machine, engine, choirmaster, director, boss, carpenter, gardener, captain, builder, mother, father, and guide. It was determined that they developed the metaphors "guidance, candle, oil lamp, light, sun, compass, traffic signs, mirror, sky, and ocean". It has been determined that some of these metaphors attribute an active role to the teacher, while others, attribute a passive role. For this reason, teacher metaphors are divided into two categories as "metaphors that assign an active role to the teacher" and "metaphors that impose a passive way on the teacher". In this context; information source, information transmitter, shaper, combine harvester, sculptor, farmer, shepherd, machine, engine, choirmaster, director, boss, carpenter, gardener, captain, builder, mother, and father metaphors were included in the category of "metaphors that put an active role on the teacher". Furthermore, the metaphors guide, guiding light, candle, oil lamp, light, sun, compass, traffic signs, mirror, sky, and ocean were coded into the category of "metaphors that impose a passive way on the teacher". According to the results of the research, it was determined that all of the participants developed metaphors and these metaphors were generally positive.

In the literature review, it was seen that similar results were obtained in many studies aiming to determine teachers' perceptions. For example, in this study, it was determined that teachers mostly produced the "sun" metaphor. Similarly; Yildizli, Erdol, Bastug and Bayram (2018) found in their meta-analysis study on teacher metaphor research in Turkey that the "sun" metaphor is among the metaphors that teachers mostly. Sokmen, Kilic and Yildirim (2020) also found that classroom teachers most often refer to teachers as "the sun". Additionally, in the same study, both prospective teachers and teachers were identified as (i) information source, (ii) productive and formative, (iii) remedial and restorative, (iv) guiding and directing, (v) example, and (vi) reassuring. It was concluded that they produced metaphors collected in the category. It is possible to say that the results of this study support the research results of Sokmen et al. (2020) The results of this research are largely in line with the results of Cakmak's (2021) research. In Cakmak's research, prospective teachers and teachers used 21 common metaphors when describing the teaching profession. These metaphors include; tree, family, mother, gardener, flower, growing flowers, farmer, sun, rainbow, life, light, pen, pole star, candle, muralist, navigation, orchestra conductor, compass, artist, water, and soil. As can be seen, similar results were obtained in this study.

According to the results obtained in this research; teachers generally adopted one of the behavioral, cognitive, and constructivist educational approaches. In this study, it has been determined that the participants adopting the behavioral and cognitive education approaches produce metaphors that assign an active role to the teacher, while the participants adopting the constructivist approach create metaphors that impose a passive role. Therefore, it has been determined that there is a clear parallelism between the metaphors that teachers produce about the teacher and the educational approaches they adopt.

Metaphors: It is possible to work in determining the attitudes of teacher candidates or teachers towards the profession. This can be considered as an opportunity for educators to evaluate themselves and to see the attitudes 
of their colleagues towards the profession. Furthermore, based on the results obtained in this research, it is possible to say that the perceptions of teachers or prospective teachers towards the teaching profession are largely shaped by the educational approaches they adopt. For this reason, metaphors developed by teachers can be used as a tool in determining the educational approaches they apply in the classroom. In a more detailed expression, metaphors guide teachers/educational and administrators/politicians in developing supervision theories, curriculum development and planning processes, regulation of learning-teaching processes, and selection of methods and strategies.

It is very important to identify metaphors for the reasons stated above. However, it is also important to determine what the metaphorical perceptions change. In this study, it was determined that metaphorical networks were affected by the educational approach adopted. However, there are of course other factors that cause the difference. For this reason, it is possible to say that there is a need for new studies in the literature to determine these factors.

\section{References}

Alkan, C. (1992). Eğitim ortamlarının düzenlenmesi. Ankara: Ankara Üniversitesi Eğitim Fakültesi Yayınları (Yayın no: 168).

Arnett, R. C. (1999). Metaphorical guidance: Administration as building and renovation. Journal of Educational Administration, 37(1), 80-89. https://doi.org/10.1108/09578239910253953

Arslan, M. M., \& Bayrakcı, M. (2006). Metaforik düşünme ve öğrenme yaklaşımının eğitim-öğretim açısından incelenmesi. Milli Eğitim Dergisi, 35(171), 100-108. Retrived from https://app.trdizin.gov.tr/makale/TmpZME56TXo

Aydin, İ. S., \& Pehlivan, A. (2010). Türkçe öğretmeni adaylarının “öğretmen” ve "öğrenci” kavramlarına ilişkin kullandıkları metaforlar. International Periodical for the Languages, Literature and History of Turkish or Turkic, 5(3), 817-842. Retrived from https://www.acarindex.com/dosyalar/makale/acarindex-1423934586.pdf

Balci, A. (2010). Açıklamalı eğitim yönetimi terimleri sözlü̆̆̈̈. Ankara: Pegem Akademi.

Basaran, İ. E. (2008). Türk eğitim sistemi ve okul yönetimi. Ankara: Ekinoks.

Ben-Peretz, M., Mendelson, N., \& Kron, F. W. (2003). How teachers in different educational context view their roles. Teaching and Teacher Education, 19, 277-290. https://doi.org/10.1016/S0742-051X(02)00100-2

Biggs, J. (1996). Enhancing teaching trought constructive alignment. Higer Education, 32, 347-364. https://doi.org/10.1007/BF00138871

Black, A. (2013). Picturing experience: Metaphor as method, data and pedagogical resource. In W. Midgley, K. Trimmer \& A. Davies (Eds.), Metaphors for, in and of education research (pp. 26-50). Newcastle upon Tyne: Cambridge Scholars Publishing. Retrived from https://core.ac.uk/download/pdf/11050507.pdf

Bower, G. H., \& Hilgard, E. R. (1981). Theories of learning (5th ed.). Englewood Cliffs, NJ: Prentice-Hall.

Cakmak, F. (2021). Öğretmen adayları ve öğretmenlerin öğretmenlik ile ilgili metaforik algılarının incelenmesi. Bayburt Eğitim Fakültesi Dergisi, 16(31), 219-251. https://doi.org/10.35675/befdergi.726660

Celikten, M. (2006). Kültür ve öğretmen metaforları. Sosyal Bilimler Enstitüsü Dergisi, 21, 269-283. Retrived from https://dergipark.org.tr/en/pub/erusosbilder/issue/23754/253096

Cerit, Y. (2008). Öğretmen kavramı ile ilgili metaforlara ilişkin öğrenci, öğretmen ve yöneticilerin görüşleri. Türk Ë̆itim Bilimleri Dergisi, 6(4), 693-712. Retrived from https://dergipark.org.tr/en/pub/tebd/issue/26110/275093

Chen, D. (2003). A classification system for metaphors about teaching. Journal of Physical Education, 74(2), 24-31. https://doi.org/10.1080/07303084.2003.10608375

Corbin, J., \& Strauss, A. (1990). Grounded theory research: Procedures, canons and evaluative criteria. Qualitative Sociology, 13(1), 3-21. https://doi.org/10.1007/BF00988593

Creed, A. (2013). Wine and metaphor: Cross-cultural [dis]harmony. In W. Midgley, K. Trimmer \& A. Davies (Eds.), Metaphors for, in and of education research (pp. 10-25). Newcastle upon Tyne: Cambridge Scholars Publishing.

Creswell, J. W. (2012). Educational research: Planning, conducting and evaluating quantative and qualitative research. Boston: Pearson. 
Culha-Ozbas, B. (2012). "Sosyal bilgiler öğretmeni olarak ben kimim?” Sosyal bilgiler öğretmenlerinin mesleki kimliklerine yönelik görüşlerinin metafor analizi yoluyla incelenmesi. Turkish Studies, 7(2), 821-838. Retrived from https://www.acarindex.com/dosyalar/makale/acarindex-1423933659.pdf

Cusi, A., \& Malara, N. A. (2016). The intertwining of theory and practise: Influences on ways of teaching and teachers' education. In L. D. English \& D. Kirshner (Eds.), Handbook of international research in mathematics education (3rd ed., pp. 516-534). New York: Routledge. https://doi.org/10.4324/9780203448946-30

De Guerrero, M. C., \& Villamil, O. S. (2001). Metaphor analysis in second/foreign language instruction: A sociocultural perspective. Revised version of paper presented at the annual meeting of the American Association of Applied Linguistics, St. Louis, MO, February 24-27, 2001. Retrieved from ERIC database.

Demirel, Ö., Seferoglu, S., \& Yagci, E. (2003). Öğretim teknoloileri ve materyal geliştirme (4th ed.). Ankara: Pegem Akademi.

Erturk, S. (1975). Ĕgitimde program geliş̧tirme. Ankara: Yelkentepe.

Gunes, F. (2007). Yapılandırıcı yaklaşımla sinıf yönetimi. Ankara: Nobel.

Gunes, F. (2010). Eğitimde yapılandırıcı yaklaşımla gelen yenilikler. Eğitime Bakış, 6(16), 3-9. Retrived from https://www.ebs.org.tr/ebs_files/files/yayinlarimiz/Egitime_Bakis_16_Sayi.pdf

Koc, E. S. (2014). Sınıf öğretmeni adaylarının öğretmen ve öğretmenlik mesleği kavramlarına ilişkin metaforik algıları. İn̈̈n̈̈ Üniversitesi Eğitim Fakültesi Dergisi, 15(1), 47-72. https://doi.org/10.17679/iuefd.79408

Lakoff, G., \& Johnson, M. (2015). Metaforlar hayat, anlam ve dil (G.Y. Demir, Trans.). İstanbul: İthaki.

Lipka, R. P., \& Brinthaupt, T. M. (1999). The role of self in teacher development. New York: SUNY Press.

Marshall, G. (2014). Sosyoloji sözlüğ̈̈. Ankara: Bilim ve Sanat.

Midgley, W., \&Trimmer, K. (2013). 'Walking the labyrinth': A metaphorical understanding of approaches to metaphors for, in and of education research. In W. Midgley, K. Trimmer \& A. Davies (Eds.), Metaphors for, in and of Education Research (pp. 1-9). Newcastle upon Tyne: Cambridge Scholars Publishing.

Miles, M. B., \& Huberman, A. M. (2015). Nitel veri analizi (S. Akbaba-Altun \& A. Ersoy, Trans.). Ankara: Pegem Akademi.

Morgan, G. (1998). Yönetim ve örgüt teorilerinde metafor (G. Bulut \& Z. Dicleli, Trans.). İstanbul: MESS Yayınları.

Nikitina, L., \& Furuoka, F. (2008). Measuring metaphors: A factor analysis of students' conceptions of language teachers. Metaphorik.de, 15, 161-180. Retrived from https://www.researchgate.net/publication/229047756_Measuring_Metaphors_A_Factor_Analysis_of_Stude nts'_Conceptions_of_Language_Teachers

Oguz, A. (2009). Öğretmen adaylarına göre ortaöğretim öğretmenlerini temsil eden metaforlar. Milli Eğitim Dergisi, 192, 36-56. Retrived from https://openaccess.dpu.edu.tr/xmlui/handle/20.500.12438/858

Oxford, R. L., Tomlinson, S., Barcelos, A., Harrington, C., Lavine, R. Z., Saleh, A., \& Longhini, A. (1998). Clashing metaphors about Classroom teachers: Toward a Systematic Typology for the Language Teaching Field. System, 26(1), 3-50. https://doi.org/10.1016/S0346-251X(97)00071-7

Palmquist, R. A. (2001). Cognitive style and users' metaphors for the web: An exploratory study. The Journal of Academic Librarianship, 27(1), 24-32. https://doi.org/10.1016/S0099-1333(00)00205-6

Parmar, D., Bertrand, J., Babu, S. V., Madathil, K., Zelaya, M., Wang, T., ... Frady, K. (2016). A comparative evaluation of viewing metaphors on psychophysical skills education in an interactive virtual environment. Virtual Reality, 20, 141-157. https://doi.org/10.1007/s10055-016-0287-7

Patton, M. Q. (2002). Qualitative research \& Evaluation methods (3rd ed.). Thousand Oaks: SAGE.

Piaget, J. (1928). Judgement and reasoning in the child. New York: Routledge.

Resnick, L. B. (1989). Knowing, learning and intruction: Essays in honor of Robert Glasser. NY: Lawrence Erlbaum.

Saban, A. (2004). Giriş düzeyindeki sınıf öğretmeni adaylarının "öğretmen” kavramına ilişkin ileri sürdükleri metaforlar. Türk Ë̆itim Bilimleri Dergisi, 2(2), 131-155. Retrived from https://dergipark.org.tr/en/pub/tebd/issue/26128/275216 
Sachs, J. (1999). Using teacher research as a basis for professional renewal. Journal of In-Service Education, 25(1), 39-53. https://doi.org/10.1080/13674589900200072

Selcuk, Z. (1997). Eğitim psikolojisi: Gelişim ve öğrenme. Ankara: Pegem Akademi.

Sokmen, Y., Yildirim, G., \& Kilic, D. (2020). Sınıf öğretmeni adaylarının ve sınıf öğretmenlerinin öğretmen kavramına yönelik metaforlarının incelenmesi. Adnan Menderes Üniversitesi Eğitim Fakültesi Ĕgitim Bilimleri Dergisi, 11(1), 1-13. Retrived from https://dergipark.org.tr/tr/pub/aduefebder/issue/55094/650725

Soysal, D., \& Afacan, Ö. (2012). İlköğretim öğrencilerinin "Fen ve teknoloji" dersi ve "Fen ve teknoloji öğretmeni” kavramlarına yönelik metafor durumları. Mustafa Kemal Üniversitesi Sosyal Bilimler Enstitüsü Dergisi, 9(19), 287-306. Retrived from https://dergipark.org.tr/en/pub/mkusbed/issue/19551/208386

Sonmez, V. (2000). Eğitimin tarihsel temelleri. In V. Sönmez, N. Senemoğlu, M. Tezcan \& C. Alkan (Eds.), Öğretmenlik mesleğine giriş. Ankara: Anı.

Sonmez, V. (2001). Program geliştirmede öğretmen el kitabı (9th ed.). Ankara: Anı.

Szukala, A. (2011). Metaphors as a tool for diagnosing beliefs about teaching and learning in social studies teacher education. Journal of Social Science Education, 10(3), 53-73. Retrived from https://pub.uni-bielefeld.de/download/2465303/2493040/Szukala-jsse-3-2011.pdf

Taskin, P. (2014). Ortaöğretim okulları öğrencilerine yönelik disiplin düzenleme ve uygulamalarının çocukların temel hak ve özgürlükleri bağlamında değerlendirilmesi. Doctoral dissertation. Ankara Üniversitesi Eğitim Bilimleri Enstitüsü, Ankara.

Turkish Language Society. (2020). Metafor. Retrived from http://www.tdk.gov.tr/index.php?option=com_gts\&arama=gts\&guid=TDK.GTS.5855872fd37c28

Ucar, R., \& Parlak-Rakap, A. (2021). Öğretmen adaylarının sınıf, sınıfta öğretmen ve sinıfta öğrenci kavramlarına iliş̧in metaforik algıları. Yüzüncü Yll Üniversitesi Eğitim Fakültesi Dergisi, 18(1), 436-460. https://doi.org/10.33711/yyuefd. 882474

Vadeboncoeur, J. A., \& Torres, M. N. (2003). Constructing and Reconstructing Teaching Roles: A focus on generative metaphors and dichotomies. Discourse: Studies in the Cultural Politics of Education, 24(1), 87-103. https://doi.org/10.1080/01596300303034

Ward, T. W. (2013). Evaluating metaphors of education. Common Ground Journal, 11(1), 13-19. Retrived from http://www.commongroundjournal.org.

Yildirim, A., \& Simsek, H. (2013). Sosyal bilimlerde nitel araştırma yöntemleri. Ankara: Seçkin.

Yildizli, H., Erdol, T. A., Bastug, M., \& Bayram, K. (2018). Türkiye'de öğretmen kavramı üzerine yapılan metafor araştırmalarına yönelik bir meta-sentez çalışması. Eğitim ve Bilim, 43(193), 1-43. https://doi.org/10.15390/EB.2018.7220

Yurdakul, B. (2007). Yapılandırmacılık. In Ö. Demirel (Ed.), Eğitimde yeni yönelimler (pp. 39-65). Ankara: Pegem Akademi. https://doi.org/10.14527/9789758792740.02

\section{Copyrights}

Copyright for this article is retained by the author, with first publication rights granted to the journal.

This is an open-access article distributed under the terms and conditions of the Creative Commons Attribution license (http://creativecommons.org/licenses/by/4.0/). 